\title{
Yields of Cadmium, Tar, Nicotine and Carbon Monoxide in Mainstream Smoke of Greek Cigarettes: A Comparative Study*
}

\author{
by \\ Kalaitroglou M. ${ }^{1}$, Samara C. ${ }^{2}$ \\ ${ }^{1}$ Tobacco Institute of Greece, Chemistry Department, Leoforos Stratou, GR 66100 Drama, Greece \\ ${ }^{2}$ Environmental Pollution Control Laboratory, Department of Chemistry, Aristotle University, \\ GR 54006 Thessaloniki, Greece
}

\section{SUMMARY}

A comparative study of the mainstream smoke chemical composition of major brands of cigarettes produced in Greece has been conducted. The concentrations of tar, nicotine, $\mathrm{CO}$ and cadmium in the mainstream smoke of 32 cigarette brands were determined. In addition, the concentration of $\mathrm{Cd}$ in cigarette tobacco was also measured and the transfer rate of $\mathrm{Cd}$ from tobacco to smoke was calculated.

Smoking of cigarettes and determination of tar, nicotine and $\mathrm{CO}$ were carried out by the ISO standard methods (ISO 8243, 3308, 4387, 10315, 10362, 3402, 8454), while the concentration of $\mathrm{Cd}$ was determined by atomic absorption spectrophotometry coupled with a graphite furnace (GF-AAS) after acid digestion of tobacco and total particulate matter (TPM) samples.

Results were explained in relation to technical specifications of cigarettes. Depending on the amount of tar, cigarettes were classified into seven groups: non filter (NF), $100 \mathrm{~mm}$ long cigarettes (L 100), high (H), medium (M), low (L), super low (SL) and ultra low tar yields (UL). Low concentrations of $\mathrm{Cd}$ were found in the tobacco of most cigarette brands $(94-572 \mathrm{ng} / \mathrm{cig})$, thus resulting in low $\mathrm{Cd}$ concentrations in TPM $(2-55 \mathrm{ng} / \mathrm{cig})$. The transfer rates of $\mathrm{Cd}$ from cigarette tobacco to TPM ranged from $2 \%$ (UL) up to $12 \%(\mathrm{H})$.

Relationships among the measured parameters were investigated by the Spearman correlation analysis. Concentrations of cadmium in TPM were strongly correlated with tar and followed the variation of Cd concentrations in cigarette tobacco. However, this tendency was not observed in ultra light cigarettes probably because of a cigarette ventilation effect. The transfer percentage of Cd in TPM was highly correlated with tar, although it was independent of the initial concentration of Cd in tobacco.

Finally, factor analysis showed that concentrations of tar, nicotine, and CO in mainstream smoke were influenced by technical specifications of cigarettes, while concentrations of $\mathrm{Cd}$ in TPM were influenced by the initial level of $\mathrm{Cd}$ in tobacco.

\section{ZUSAMMENFASSUNG}

Eine vergleichende Untersuchung der chemischen $\mathrm{Zu}$ sammensetzung der wichtigsten in Griechenland produzierten Cigarettenmarken wurde durchgeführt. Die Konzentrationen des nikotinfreien Trockenkondensats, Nikotins und Cadmiums im Rohkondensat sowie der CO Gehalt im Hauptstromrauch von 32 Cigarettenmarken wurden bestimmt. Darüber hinaus wurden der Cadmiumgehalt im Cigarettentabak und der prozentuale Anteil des Cadmiumtransferts in den Hauptstromrauch berechnet. 
Das Abrauchen der Cigaretten und der Gehalt an nikotinfreiem Trockenkondensat, Nikotin und CO im Hauptstromrauch wurde gemäß den ISO-Normen $8234,3308,4387,10315,10362,3402$ und 8454 vorgenommen. Die Cadmiumkonzentration im Tabak und im Rohkondensat wurde mit Hilfe der Atomabsorptionsspektroskopie im Grafitofen (GF-AAS) nach saurem Aufschluss der Proben bestimmt.

Die Ergebnisse wurden zu den Designmerkmalen der Cigaretten in Beziehung gesetzt. Entsprechend ihres Kondensatgehalts wurden die Cigaretten in sieben Gruppen unterteilt: ohne Filter (NF), $100 \mathrm{~mm}$ Cigaretten (L 100), kondensatreiche Cigaretten $(\mathrm{H})$, Medium (M), Leicht (L), Superleicht (SL) und Ultraleicht (UL). In den meisten Cigarettenmarken wurden niedrige Cadmiumwerte im Tabak gefunden (94-572 ng/Cigarette), was zu niedrigen Cadmiumkonzentrationen im Kondensat führte (2-55 ng/Cigarette). Die Transferraten des Cadmiums vom Tabak zum Kondensat lagen zwischen $2 \%$ (UL) und $12 \%(\mathrm{H})$.

Die Beziehung zwischen den gemessenen Parametern wurde mit der Spearmanschen Rangkorrelationsanalyse berechnet. Die Konzentration des Cadmiums im Rohkondensat korrelierte stark mit dem Gehalt an nikotinfreiem Trockenkondensat und variierte entsprechend der Cadmiumkonzentration im Tabak. Dieser Zusammenhang konnte jedoch bei Ultraleichtcigaretten, vermutlich aufgrund des Ventilationseffektes, nicht beobachtet werden. Die Transferrate des Cadmiums in das Rohkondensat korrelierte zwar stark mit dem Gehalt an nikotinfreiem Trockenkondensat, es gab jedoch keinen $\mathrm{Zu}$ sammenhang zur ursprünglichen Cadmiumkonzentration im Tabak.

Schließlich zeigte die Faktorenanalyse, dass die Konzentration des nikotinfreien Trockenkondensats und des Nikotins im Rohkondensat sowie CO im Hauptstromrauch durch die Designmerkmale der Cigaretten beeinflusst werden, während die Konzentration des Cadmiums im Rohkondensat vom ursprünglichen Cadmiumgehalt im Tabak abhängt.

\section{RESUME}

Une étude comparative a été réalisée dans le but d'analyser la composition chimique des principales marques de cigarettes grecques. Les teneurs en goudrons, nicotine et cadmium dans la matière particulaire totale (MPT) de même que la teneur en $\mathrm{CO}$ de la fumée du courant principal (FCP) de 32 marques de cigarettes grecques ont été déterminées. En outre, on a dosé la concentration en cadmium dans le tabac et calculé le taux de transfert du cadmium dans la fumée du courant principal.

Le fumage des cigarettes et la détermination de la teneur en goudrons, nicotine et $\mathrm{CO}$ ont été réalisés selon les normes ISO 8243, 3308, 4387, 10315, 10362, 3402, 8454, tandis que la teneur en cadmium a été mesurée par spectrophotométrie par absorption atomique couplée à un four graphite (GF-AAS) après digestion acide du tabac ou des échantillons de MPT. Les résultats ont été étudiés en relation avec les propriétés technologiques de cigarettes. Celles-ci ont été classées en sept groupes en fonction de leur teneur en goudrons: sans filtre (NF), cigarettes de $100 \mathrm{~mm}(\mathrm{~L}$ $100)$, plein arôme $(\mathrm{H})$, moyennes $(\mathrm{M})$, légères $(\mathrm{L})$, 'super' - légères (SL) et ultra - légères (UL). De faibles teneurs en cadmium ont été trouvées dans le tabac de la plupart des marques (94-572 ng/cigarette) entraînant de faibles teneurs en cadmium dans la MPT (2-55 ng/cigarette). Les taux de transfert du cadmium du tabac à la MPT varient de $2 \%$ (pour les cigarettes ultra-légères) à $12 \%$ (pour les cigarettes plein arôme).

L'analyse de corrélation selon Spearman a permis d'étudier la relation entre les paramètres mesurés. La teneur en cadmium de la MPT est étroitement liée à la teneur en goudrons et varie selon la teneur en cadmium du tabac. Cette tendance disparaît chez les cigarettes ultra - légères, probablement en raison de la ventilation. Le taux de transfert du cadmium dans la MPT est étroitement corrélé à la teneur en goudrons, il n'est cependant pas en relation avec la teneur en cadmium du tabac.

Enfin, l'analyse factorielle indique que la teneur en goudrons et nicotine dans la MPT et le rendement en $\mathrm{CO}$ dans la FCP sont influencés par les paramètres technologiques des cigarettes, tandis que le rendement en cadmium dans la MPT est lié à la teneur en cadmium du tabac.

\section{INTRODUCTION}

In 1997, approximately 261 brands of cigarettes were sold on the Greek market, 145 of which were foreign brands, either imported or produced in Greece under license and 116 were domestic. During the last ten years, cigarette consumption in Greece has ranged between 28.2 and 29.9 billion pieces per year. Taking into consideration the average daily cigarette consumption and assuming that an average smoker consumes approximately 20 cigarettes per day, the number of smokers in Greece is estimated to be approximately four million, which is almost $40 \%$ of the total population. Figure 1 illustrates cigarette consumption from 1980 until 1997 (1).

From the consumption data it is evident that the campaign against smoking has not shown considerable results so far, probably due to the fact that tobacco and its products are a very powerful income source for the Greek economy. Tobacco exports (80-90\% of the total production) 
contribute approximately 300 million U.S. dollars per year to the economy. In addition, cigarette and other tobacco products account for about $6 \%$ of the total government tax income ( $\sim 1.8$ billion dollars in 1996). Moreover, a significant number of Greeks are occupied in the cultivation, processing and sale of tobacco and its products (2).

The aim of this study was to compare the most popular cigarette brands of the Greek market with regard to certain chemical constituents, and hence evaluate the health risk that they impose on smokers. For this purpose, TPM of mainstream smoke (MS) was analyzed for nicotine-free dry particulate matter (tar), cadmium and nicotine. Carbon monoxide was measured in the vapor phase of MS. Cadmium was also determined in the tobacco of cigarettes and its transfer rate to the particulate phase of MS was calculated. Experimental data were related to the technical specifications of each cigarette brand. Multivariate statistical methods were also used to investigate the relationships among analyte concentrations and to discriminate differences in MS composition patterns among cigarette types.

\section{MATERIALS AND METHODS}

Thirty-two of the most popular brands of cigarettes produced in Greece $(12 \%$ of the total number of brands in the market) were sampled from cigarette manufacturers in 1997. These brands represent about $50 \%$ of the total cigarettes. Twenty-seven of them were domestic brands, while the rest were foreign brands produced in Greece under license. Sampling was carried out according to the method recommended by ISO 8243 (1991). Before the analytical measurements were made, cigarettes were conditioned for $24 \mathrm{hrs}$ at $22{ }^{\circ} \mathrm{C}$ and $60 \%$ humidity to achieve constant weight and moisture (ISO 3402 (1991)). Twenty cigarettes from each brand were smoked according to ISO 3308 (1991). TPM was collected with a 92-mm Cambridge filter pad to determine TPM and tar (ISO 4387 (1991)). A Borgwald RM20CS smoking machine was employed. The determination of nicotine and water on Cambridge filter pads was performed by gas chromatography according to ISO 10315 (1991) and 10362 (1991) standard methods, respectively.

Cigarettes were also smoked under ISO conditions using an 8-channel piston-operated smoking machine (Filtrona Int. Ltd., model 302). The TPM of MS was collected on Cambridge filter pads (4 $\mathrm{mm}$ diam.). Two Cambridge filters from each cigarette brand containing the smoke condensation from 10 cigarettes were used for the determination of Cd in the TPM of MS. The vapor phase of MS was channeled into a polyethylene bag connected to a non-dispersive infrared CO analyzer ISO 8454 (1995).

The transfer rate of Cd to the TPM of MS was calculated from its concentrations in TPM and the tobacco column which would be smoked under ISO conditions (the tobacco column is defined as whole cigarette minus the filter $+8 \mathrm{~mm}$ of tobacco column for filter cigarettes, or the whole cigarette minus $23 \mathrm{~mm}$ of tobacco column for non-filter cigarettes).

The preparation of samples for the determination of $\mathrm{Cd}$ in tobacco columns, including paper, and in condensate smoke on the pads is shown in Figure 2.

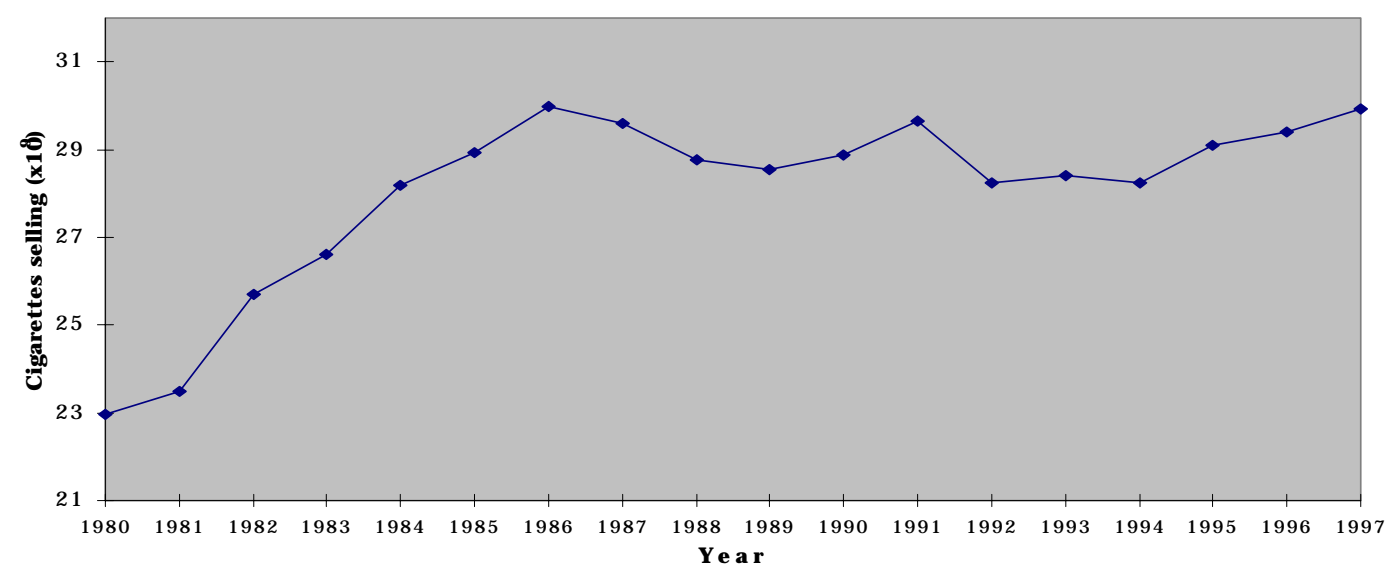

Figure 1.

Trends of cigarette consumption in Greece during the period 1980-1997 (Data obtained from the National Tobacco Board of Greece). 
In both cases the procedures suggested by WESTCOTT and SPINCER were applied (3), except that cigarette columns were digested with only $30 \mathrm{~mL}$ concentrated nitric acid because results were equivalent to those obtained by digestion in a mixture (30:2) of concentrated $\mathrm{HNO}_{3}$ and $\mathrm{HClO}_{4}$ acids. The analysis of $\mathrm{Cd}$ was performed on a Perkin-Elmer Model 2380 atomic absorption spectrophotometer coupled with a graphite furnace (HGA-400) and an electrodeless discharge Cd lamp. The operation parameters and the temperature program were similar with those described in (4). Briefly, the instrument settings for temperature $\left({ }^{\circ} \mathrm{C}\right) /$ ramp time $(\mathrm{s}) /$ hold time $(\mathrm{s})$ were as follows: drying $(300 / 5 / 5)$, charring $(300 / 5 / 5)$, atomization (2100/1/5) and cleaning (2300/1/1).

Smoking of cigarettes and subsequent analyses were performed in duplicate. Due to the lack of certified reference materials (Reference cigarettes with known Cd levels), the quality of the analytical results was assured by blanks, calibration standard spiked samples and the method of standard additions on treated samples. Procedural blanks (no sample) were run with every set of TPM and tobacco column digestions. Cambridge filters were found to contribute to Cd in TPM by $1.5 \mathrm{ng} / \mathrm{cig}$, while concentrated nitric acid contributed to $\mathrm{Cd}$ in tobacco columns by $60 \mathrm{ng} / \mathrm{cig}$. All data reported here are blank corrected. The recovery efficiency of $\mathrm{Cd}$ from spiked samples was $85 \%$ and $82 \%$ from TPM and to- bacco, respectively (mean of two determinations). Data were not corrected from recovery. The analytical variation of Cd determinations was $\leq 10 \%$ for both sample types.

\section{RESULTS AND DISCUSSION}

\section{Classification of cigarettes}

In order to draw conclusions, the 32 brands of cigarettes examined were classified into seven groups with respect to the existence of filter or not, the tar indicated on the packet, and the cigarette length. The classification of cigarettes is shown in Table 1.

\section{Tar, nicotine, moisture and CO in mainstream smoke}

Results obtained from the analysis of mainstream smoke for tar, nicotine, moisture and CO are presented in Table 2.

The results of Table 2 indicate that the dry tobacco weight smoked decreases from high tar yield cigarettes (L 100 or $\mathrm{H}$ ) to ultra low cigarettes. This was anticipated since less tobacco smoked should yield less tar (5). It can also be observed that, although the tobacco column smoked in non-filter cigarettes is less $(45 \mathrm{~mm})$ than in
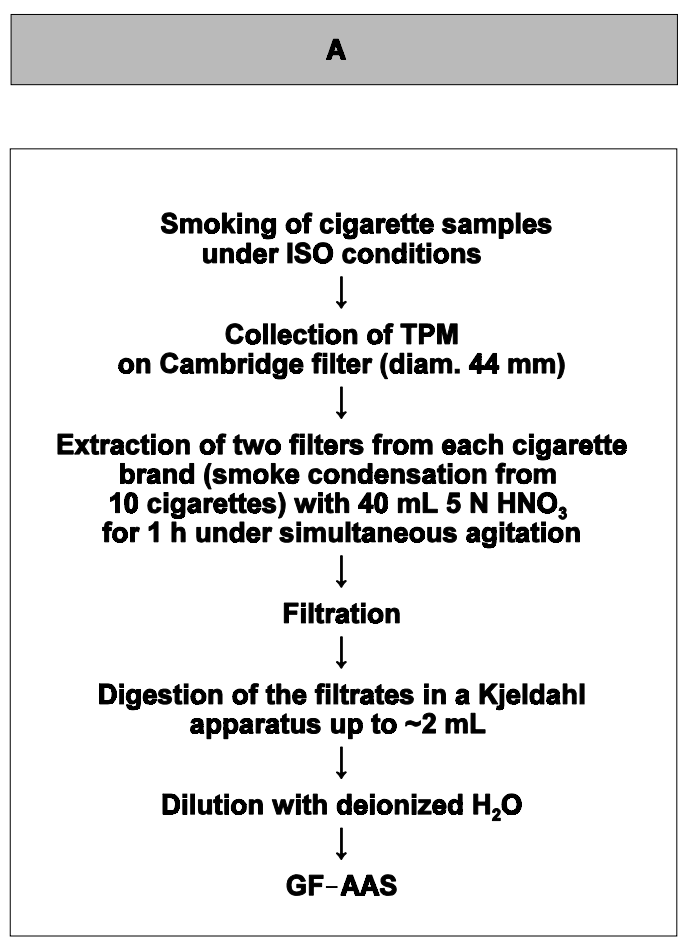

\section{B}

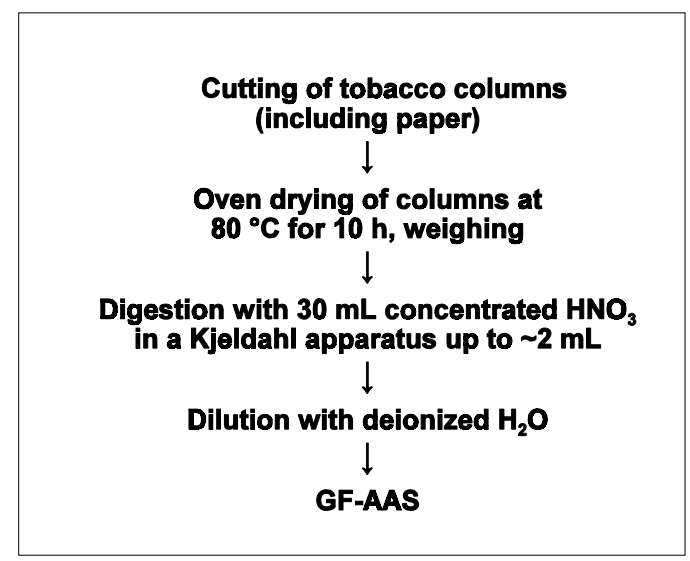

Figure 2.

Experimental procedure for the determination of $\mathrm{Cd}$ in a) TPM of mainstream smoke; b) tobacco columns. 
Table 1.

Classification of cigarette brands.

\begin{tabular}{lcc|l}
\hline Cigarette type & Filter & Length $(\mathrm{mm})$ & \multicolumn{1}{c}{ Tar content $(\mathrm{mg} / \mathrm{cig})$} \\
\hline Non-filter & No & 68 & $18(1)^{\mathrm{a}}, 15(3)$ \\
$100 \mathrm{~mm}$ long & Yes & 100 & $17(1), 16(1), 14(2)$ \\
High tar yield & Yes & 84 & $14(7), 13(8)$ \\
Medium tar yield & Yes & 84 & $12(1), 11(1), 10(1)$ \\
Low tar yield & Yes & 84 & $8(4), 7(2)$ \\
Super low tar yield & Yes & 84 & $6(1), 4(1)$ \\
Ultra low tar yield & Yes & 84 & $2(1), 1(4)$ \\
\hline
\end{tabular}

${ }^{a}$ Number of brands examined in parentheses

84-mm length filter cigarettes $(56 \mathrm{~mm})$, the amount of tobacco smoked in non-filter cigarettes is similar or higher than in filter cigarettes. This confirms the fact that non-filter cigarettes have a higher filling density.

Nicotine yields showed the same pattern as tar, highest values being observed in $100-\mathrm{mm}$ length cigarettes.

Carbon monoxide also decreased from high to ultra low tar yield cigarettes, this was mainly due to the increasing degree of filter ventilation. It is noteworthy that CO concentrations in the MS of non-filter cigarettes were lower than in high tar yield cigarettes. This could be attributed to the fact that: a) the conventional acetate cellulose filters do not contribute to the removal of $\mathrm{CO}$,

b) the lower pressure drop in non-filter cigarettes favors easier entrance of atmospheric oxygen into the inner cigarette, thus enhancing complete combustion.

Transfer of $C d$ from cigarette tobacco to mainstream smoke

Cadmium concentrations (mean of two determinations) found in the tobacco column of each cigarette brand are

Table 2.

Concentrations of tar and nicotine in TPM and $\mathrm{CO}$ in mainstream smoke of different cigarette groups.

\begin{tabular}{|c|c|c|c|c|c|c|}
\hline Cigarette type & & $\begin{array}{c}\text { Dry tobacco weight }{ }^{a} \\
\text { (g/cig.) }\end{array}$ & $\begin{array}{l}\text { Puff } \\
\text { number }\end{array}$ & $\begin{array}{c}\text { Tar } \\
\text { (mg/cig.) }\end{array}$ & $\begin{array}{l}\text { Nicotine } \\
\text { (mg/cig.) }\end{array}$ & $\begin{array}{c}\mathrm{CO} \\
\text { (mg/cig.) }\end{array}$ \\
\hline \multirow[t]{2}{*}{ Non-filter } & $(n=4)^{b}$ & 0.603 & 7.2 & 16 & 1.1 & 9 \\
\hline & $(\min -\max )$ & $(0.576-0.642)$ & $(6.6-7.7)$ & $(13-18)$ & $(1.0-1.3)$ & $(6.9-12.9)$ \\
\hline \multirow[t]{2}{*}{$100 \mathrm{~mm}$ long } & $(n=4)$ & 0.722 & 8.8 & 16 & 1.3 & 12.5 \\
\hline & $(\min -\max )$ & $(0.687-0.789)$ & $(8.4-9.7)$ & $(14-17)$ & $(1.1-1.5)$ & $(10.2-14.7)$ \\
\hline \multirow[t]{2}{*}{ High tar yield } & $(\mathrm{n}=8)$ & 0.591 & 7.8 & 14 & 1.1 & 10.7 \\
\hline & $(\min -\max )$ & $(0.504-0.625)$ & (7.2-8.3) & $(15-11)$ & $(1.3-0.9)$ & $(9.0-12.9)$ \\
\hline \multirow[t]{2}{*}{ Medium tar yield } & $(n=3)$ & 0.611 & 7.7 & 12 & 0.8 & 9.4 \\
\hline & $(\min -\max )$ & $(0.564-0.675)$ & $(7.0-8.3)$ & $(9.8-14)$ & $(0.7-1.1)$ & $(8.3-10.4)$ \\
\hline \multirow[t]{2}{*}{ Low tar yield } & $(\mathrm{n}=6)$ & 0.569 & 7.7 & 8.1 & 0.7 & 6.1 \\
\hline & $(\min -\max )$ & $(0.521-0.628)$ & $(6.7-8.5)$ & $(6.7-7.0)$ & $(0.6-0.9)$ & $(5.2-7.4)$ \\
\hline \multirow[t]{2}{*}{ Super low tar yield } & $(n=2)$ & 0.532 & 7.7 & 4.8 & 0.5 & 3.4 \\
\hline & $(\min -\max )$ & - & $(7.2-8.2)$ & $(4.3-5.4)$ & $(0.4-0.6)$ & - \\
\hline \multirow[t]{2}{*}{ Ultra low tar yield } & $(n=5)$ & 0.509 & 7.9 & 1.3 & 0.11 & 1.9 \\
\hline & $(\min -\max )$ & $(0.454-0.526)$ & $(6.8-8.7)$ & $(0.9-1.7)$ & $(0.05-0.22)$ & $(0.8-3.4)$ \\
\hline
\end{tabular}




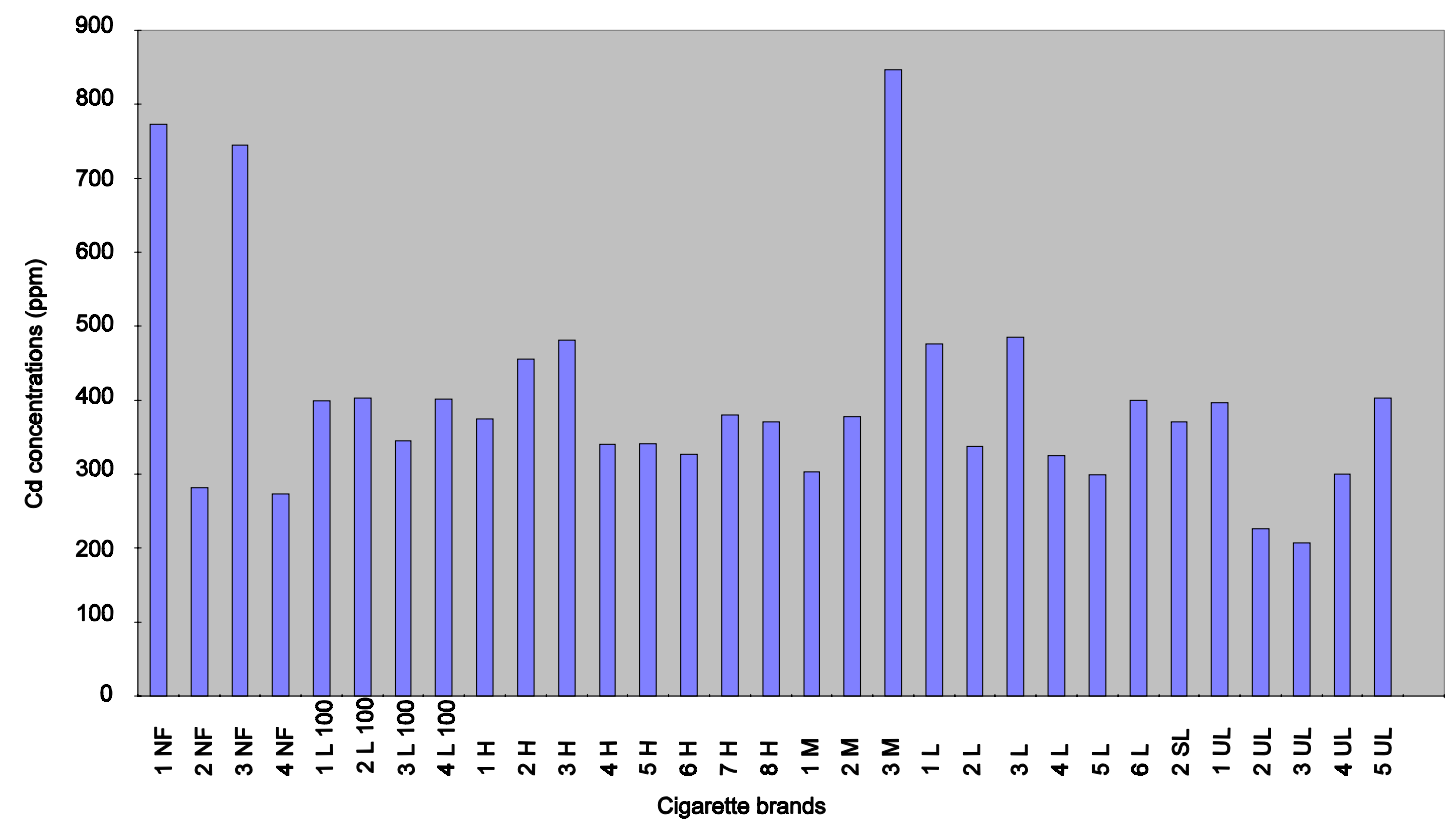

Figure 3.

Cadmium concentrations in cigarette tobacco columns $(\mathrm{ng} / \mathrm{g}$ dry weight of tobacco column including cigarette paper): $N F=$ non-filter; $L 100=100 \mathrm{~mm}$ long; $H$ = high tar yield; $M=$ medium tar yield; $L=$ low tar yield; $S L=$ super low tar yield; UL = ultra low tar yield. (Sample $1 \mathrm{SL}$ was not analysed for Cd due to the limited number of available cigarettes).

presented in Figure 3. Apart from few exceptions, the majority of brands had a tobacco Cd content in the range of 207 to $485 \mathrm{ng} / \mathrm{g}$ dry weight. These values are lower than those reported for cigarette brands produced

Table 3.

Mean cadmium levels in tobacco blends of commercial cigarettes in different countries.

\begin{tabular}{|c|c|c|c|c|c|}
\hline \multirow{2}{*}{ Country } & \multirow{2}{*}{ Year } & \multirow{2}{*}{ Reference } & \multirow{2}{*}{$\begin{array}{l}\text { Number of } \\
\text { samples }\end{array}$} & \multicolumn{2}{|c|}{ Cadmium $(\mu \mathrm{g} / \mathrm{g})$ d.w. } \\
\hline & & & & Mean $\pm S D^{a}$ & Range \\
\hline Canada & 1975 & (9) & 68 & 2.75 & $1.40-7.02$ \\
\hline New Zealand & 1979 & (8) & 62 & - & $0.23-0.562^{b}$ \\
\hline Germany & 1979 & (9) & 15 & $1.46 \pm 0.34$ & $1.07-2.30$ \\
\hline Germany & 1979 & (10) & 4 & $0.92 \pm 0.21$ & $0.75-1.22$ \\
\hline Austria & 1982 & (10) & 10 & $1.55 \pm 0.34$ & $0.86-1.96$ \\
\hline Germany & 1982 & (10) & 10 & $1.02 \pm 0.32^{c}$ & $0.48-1.59^{\circ}$ \\
\hline Finland & $1979-80$ & (15) & 44 & $1.4 \pm 0.4$ & - \\
\hline 22 Regions worldwide & 1987 & (14) & 331 & 1.45 & - \\
\hline USA & 1990 & (11) & 10 & $0.99 \pm 0.49$ & $0.89-1.08$ \\
\hline Austria & 1991 & (12) & 14 & $0.80 \pm 0.29$ & $0.26-1.38$ \\
\hline Greece & 1997 & present study & 32 & $0.35 \pm 0.14$ & $0.21-0.85$ \\
\hline
\end{tabular}

${ }^{\mathrm{a}} \mathrm{SD}=$ Standard deviation $\quad{ }^{\mathrm{b}} 60 \%$ Relative humidity $\quad{ }^{\mathrm{c}} \mu \mathrm{g} /$ cigarette 
Table 4.

Cadmium content in tobacco and TPM (mean; min-max) and transfer rate.

\begin{tabular}{|c|c|c|c|c|}
\hline Cigarette type & & $\begin{array}{l}\text { Cd content in tobacco } \\
\text { (ng/cig.) }\end{array}$ & $\begin{array}{l}\text { Cd content in TPM } \\
\text { (ng/cig.) }\end{array}$ & $\begin{array}{c}\text { Transfer rate } \\
(\%)\end{array}$ \\
\hline \multirow[t]{2}{*}{ Non-filter } & $(n=4)$ & 318 & 28 & 9.4 \\
\hline & $(\min -\max )$ & $(157-496)$ & $(17-43)$ & $(7-12)$ \\
\hline \multirow[t]{2}{*}{$100 \mathrm{~mm}$ long } & $(n=4)$ & 280 & 26 & 9.2 \\
\hline & $(\min -\max )$ & (237-318) & $(19-33)$ & $(7-11)$ \\
\hline \multirow[t]{2}{*}{ High tar yield } & $(n=8)$ & 225 & 26 & 12 \\
\hline & $(\min -\max )$ & $(180-291)$ & $(12-37)$ & $(5.5-15)$ \\
\hline \multirow[t]{2}{*}{ Medium tar yield } & $(n=3)$ & 321 & 30 & 9.2 \\
\hline & $(\min -\max )$ & $(179-572)$ & $(16-55)$ & $(8-10)$ \\
\hline \multirow[t]{2}{*}{ Low tar yield } & $(n=6)$ & 212 & 11 & 5 \\
\hline & $(\min -\max )$ & $(161-298)$ & $(5-15)$ & $(3-7)$ \\
\hline \multirow[t]{2}{*}{ Super low tar yield } & $(n=2)$ & 186 & 4 & 2.2 \\
\hline & $(\min -\max )$ & - & - & - \\
\hline \multirow[t]{2}{*}{ Ultra low tar yield } & $(n=5)$ & 158 & 2.8 & 1.9 \\
\hline & (min-max) & $(94-231)$ & $(1.3-5)$ & $(0.8-2.2)$ \\
\hline
\end{tabular}

in other countries (Table 3), and could possibly be attributed to the low $\mathrm{Cd}$ content of agricultural soils in the areas where tobacco is cultivated in Greece (6).

Mean Cd content and the range of $\mathrm{Cd}$ content in the tobacco columns of each cigarette group are given in Table 4. The Cd content in the TPM of MS and the Cd transfer rate are also given.

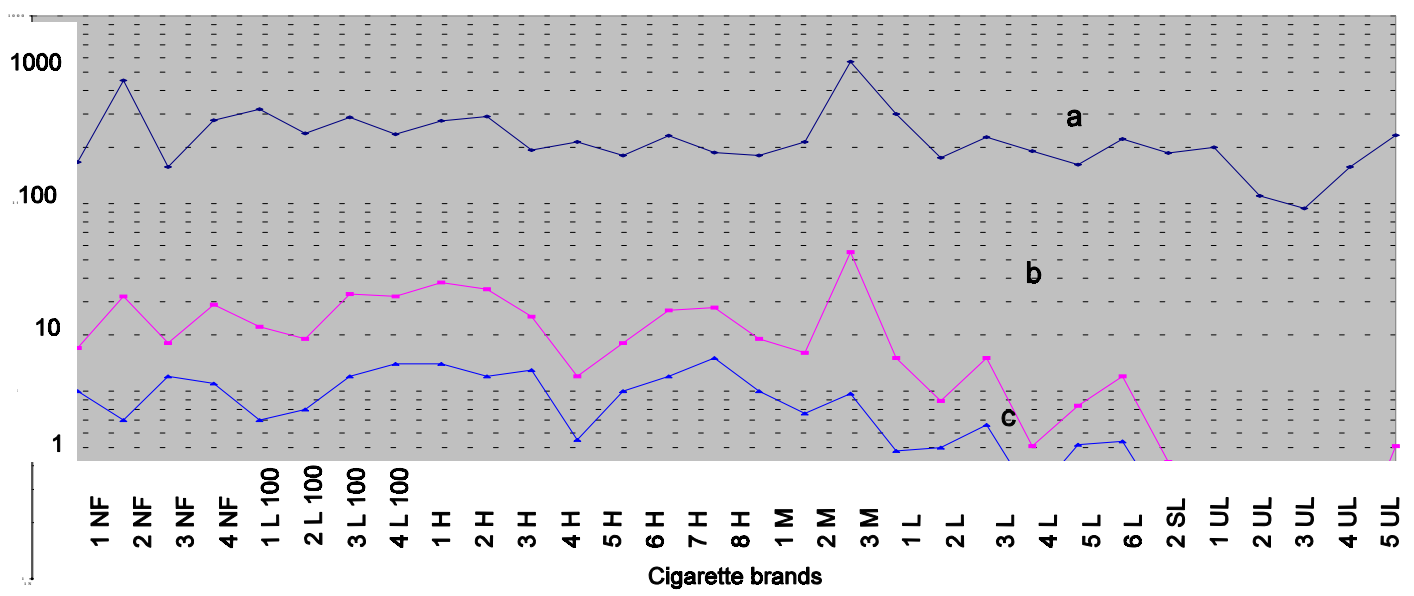

Figure 4.

Variability of a) Cd in cigarette tobacco (ng/cig); b) Cd in TPM of mainstream smoke; c) Cd transfer rate (\%). $\mathrm{NF}=$ non-filter; $\mathrm{L} 100=100 \mathrm{~mm}$ long; $\mathrm{H}=$ high tar yield; $\mathrm{M}=$ medium tar yield; $\mathrm{L}=$ low tar yield; $\mathrm{SL}$ = super low tar yield; UL = ultra low tar yield. (Sample $1 \mathrm{SL}$ was not analysed for $\mathrm{Cd}$ for the reasons given in Figure 3). 
Table 5.

Spearman rank correlation coefficients ${ }^{\text {a }}$.

\begin{tabular}{r|c|c|c|c|c|c}
\hline Analyses performed & Tar & Nicotine & CO & $\begin{array}{c}\text { Cd } \\
\text { in tobacco }\end{array}$ & $\begin{array}{c}\text { Cd } \\
\text { in TPM }\end{array}$ & $\begin{array}{c}\text { Transfer } \\
\text { rate }\end{array}$ \\
\hline Tar & 0.838 & 0.852 & 0.525 & 0.868 & 0.799 \\
\hline Nicotine & & 0.813 & & 0.649 & 0.703 \\
\hline CO & & & 0.420 & 0.806 & 0.870 \\
\hline Cd in tobacco & & & & 0.702 & \\
\hline Cd in TPM & & & & & 0.839 \\
\hline
\end{tabular}

${ }^{a}$ Only coefficients significant at $>95 \%$ confidence level are given. Coefficients significant at the $99 \%$ confidence level are italicized.

It is evident that the concentration of $\mathrm{Cd}$ in the TPM of mainstream smoke as well as the transfer rate of $\mathrm{Cd}$ from cigarette tobacco to MS decreased from high tar to low tar cigarettes. This may be attributed to the technical specifications of light cigarettes and filters (ventilation, porous cigarette paper etc.) (7).
Cadmium in TPM of MS and cadmium in tobacco showed similar variability patterns (Figure 4). This relationship was found to disappear in ultra light cigarettes probably because of the effect of cigarette ventilation. Relative similarity can also be observed in the variability patterns of Cd in TPM and the Cd transfer rate. a

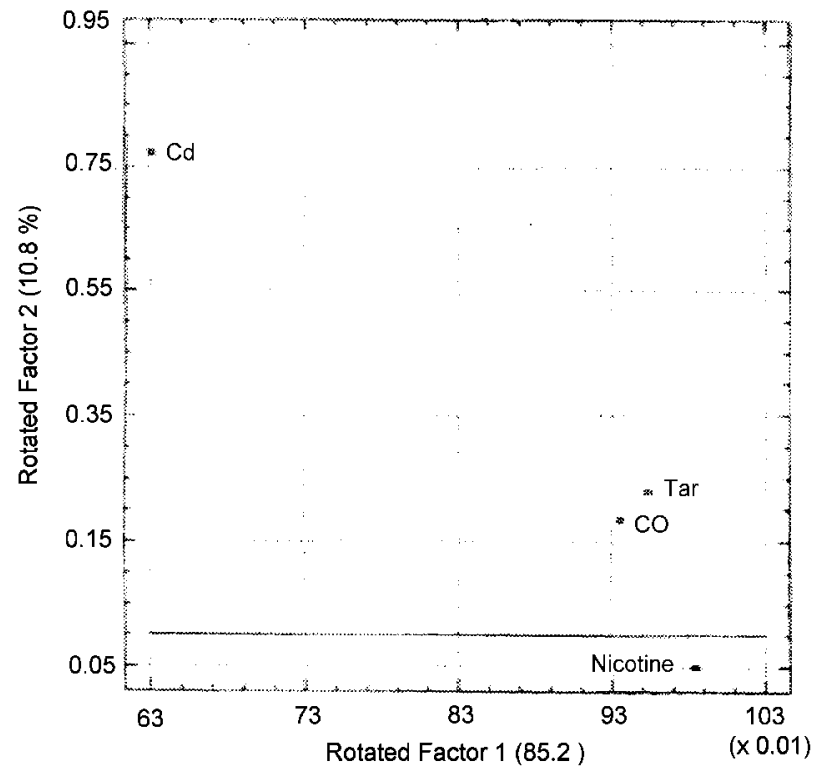

b

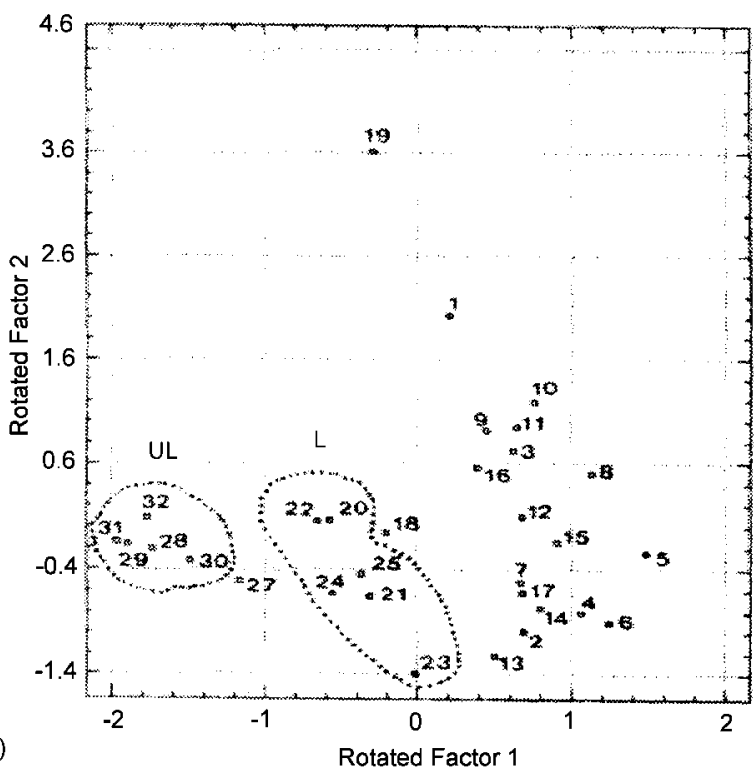

\section{Figure 5.}

Factor analysis of nicotine, tar, $\mathrm{Cd}$ and $\mathrm{CO}$ in mainstream smoke of various cigarette brands: $\mathrm{NF}=$ non-filter; $L \mathbf{1 0 0}=100$ mm long; $H$ = high tar yield; $M$ = medium tar yield; $L=$ low tar yield; $S L$ = super low tar yield; UL = ultra low tar yield ( $\mathrm{n}=32$ : NF (1-4); L 100 (5-8); H (9-16); M (17-19); L (20-25); SL (27); UL (28-32); sample $1 \mathrm{SL}(26)$ is missing for the reasons given in Figure 3 ). 
Results shown in Table 4 indicate that L 100 cigarettes have lower $\mathrm{Cd}$ transfer rates than high tar cigarettes. This is probably due to the longer $(24 \mathrm{~mm})$ cellulose acetate filter used in L 100 brands compared to the $20-\mathrm{mm}$ filter used in high tar cigarettes. Nevertheless, the Cd transfer rates in nonfilter cigarettes were also lower than those in high tar cigarettes. This needs further confirmation since other investigators have found lower transfer rates in filter cigarettes than in non-filter cigarettes (13-15). In general, the $\mathrm{Cd}$ transfer rates calculated for cigarettes produced in Greece are comparable to reported values ranging from $3.8 \%$ to $20 \%$ and $2.5 \%$ to $12 \%$ for non-filter and filter cigarettes, respectively (10).

\section{Correlation analysis}

The univariate correlations among the chemical parameters determined in cigarette mainstream smoke and tobacco column were investigated by employing the non-parametric Spearman rank correlation method, as the Kolmogorov-Smirnov test showed that most analytes did not follow a normal distribution. Correlation coefficients derived are given in Table 5.

As shown, tar was primarily correlated to nicotine, $\mathrm{CO}$ and $\mathrm{Cd}$ in the TPM of mainstream smoke, and secondarily to $\mathrm{Cd}$ in tobacco. The transfer rate of $\mathrm{Cd}$ in tobacco to TPM was strongly correlated with $\mathrm{Cd}$ in TPM, however, it seems to be independent of $\mathrm{Cd}$ in cigarette tobacco.

Correlation analyses were also performed on cigarettes with a tar content of $13-18 \mathrm{mg} / \mathrm{cig}$ to investigate the relationship between the puff number per cigarette and the weight, or the length of the tobacco column smoked. It was found that the puff number/cig is strongly correlated with the length of the tobacco column smoked $(r=0.827, p=0.01)$, while a weaker correlation was derived with column weight $r=0.632, p=0.05$ ).

\section{Factor analysis}

Factor analysis (FA) has been used to discriminate differences in mainstream smoke composition patterns among cigarette groups.

FA is a multivariate statistical method that groups original variables of a data set into new orthogonal variables (factors), which are linear combinations of the original data. FA can be viewed as a projection method where the intention is to preserve as much as possible of the variance in the original data set.
FA was performed on concentration data for tar, nicotine, $\mathrm{CO}$ and $\mathrm{Cd}$ in mainstream smoke and was run on STATGRAPHICS 5.0 software (16).

Variable loadings and factor scores obtained are illustrated in Figures $5 \mathrm{a}$ and $\mathrm{b}$. After varimax rotation, two factors were found to explain $96 \%$ of the total variance within the original data set. The first factor, accounting for $85.2 \%$ of total variance, showed high loadings primarily for tar, nicotine and CO, while secondarily for $\mathrm{Cd}$. This factor could be interpreted as representing the physicochemical characteristics of cigarettes. The second factor, accounting for $10.8 \%$ of total variance, was associated only with $\mathrm{Cd}$ in TPM. This factor may be related to the original $\mathrm{Cd}$ content in cigarette tobacco.

Factor scores (Figure 5b) reveal that mainstream smoke of ultra low tar yield cigarettes have a similar compositional pattern that is characterized by low concentrations of tar, nicotine, CO and Cd in TPM, presumably due to the effect of ventilation. A similar compositional pattern was observed for the MS of low tar yield cigarettes.

\section{CONCLUSIONS}

1. The concentration of nicotine and $\mathrm{CO}$ was positively correlated with the concentration of tar in mainstream smoke TPM. Carbon monoxide was lower in plain cigarettes than in filter cigarettes revealing that the filter does not remove $\mathrm{CO}$.

2. Almost all brands of this study appear to have similar $\mathrm{Cd}$ concentrations in tobacco. These values are considerably lower compared to literature data and are attributed to the low concentration of $\mathrm{Cd}$ in Greek tobacco soils.

3. Cd in TPM was strongly correlated to the tar yield and followed the fluctuations of $\mathrm{Cd}$ in cigarette tobacco, a tendency which disappeared from light to ultra light cigarettes, probably due to the filter ventilation. The transfer rate of $\mathrm{Cd}$ from cigarette tobacco to TPM was also strongly correlated to the tar yield, but it was independent of the concentration of $\mathrm{Cd}$ in tobacco.

4. Factor analysis showed that the concentration of tar, nicotine and CO in MS is influenced by technical specifications of cigarettes, while the concentration of Cd in TPM is influenced by the content of cadmium in cigarette tobacco. 
Acknowledgments

The authors wish to thank Dr. D. Voutsa from the Environmental Pollution Control Laboratory as well as Chemist S. Chalyvopoulos, $S$. Divanides and P. Vassiliadou at the Tobacco Institute for technical assistance and helpful discussion.

\section{REFERENCES}

1. Tobacco Industries Union: personal communication.

2. Dimara E. and D. Skouros: The cultivation of tobacco in Greece; Ombris Publications, Athens, 1997.

3. Westcott, D.T. and D. Spincer: The cadmium, nickel and lead content of tobacco and cigarette smoke; Beitr. Tabakforsch. 7 (1974) 217-221.

4. Perinelli M.A. and N. Carugno: Determination of trace metal in cigarette smoke by flameless atomic absorption spectrometry; Beitr. Tabakforsch. Int. 9 (1978) 214-217.

5. DeBardeleden, M.Z., W.E. Clafin and W.F. Gannan: Role of cigarette physical characteristics on smoke composition; Rec. Adv. Tob. Sci. 4 (1978) 85-112.

6. Tobacco Institute of Greece: personal communication.

7. Figueres, G.: Le transfert du cadmium dans la Fumee de cigarette; Ann. du Tabac. 26, Section 2 (1994) 71-88.

8. Brooks R.R. and J.M. Trow: Lead and cadmium of some New Zealand and overseas cigarettes. New Zealand J. Sci. 22 (1979) 289-91.

9. Mueller, G.: Heavy metal content $(\mathrm{Cd}, \mathrm{Zn}, \mathrm{Pb}, \mathrm{Cu}$, $\mathrm{Cr}$ ) of tobacco in commonly smoked cigarettes in the Federal Republic of Germany; Chem. Zeit 103 (4) (1979) 133-137.
10. Scherer G. and F. Adlkofer: Cadmium in tobacco and tobacco smoke; Abstract, Bulletin Spécial Coresta, Vienna Congres, 1984, p 37.

11. Bell P. and C. Mulchi: Heavy metal concentration in cigarette blends; Tob. Sci. 33 (1994) 32-34.

12. Nitsch A. and K. Kalcher: Schwermetalle in Tabaken und in Tabakrauch II: Spurenelemente Cadmium, Blei, Kupfer, Kobalt und Nickel in österreichischen Zigaretten und deren Rauchkondensaten und Rauchgasen; Beitr. Tabakforsch. Int. 15 (1991) 19-32.

13. Krivan V., G. Schneider, H. Baumann, U. Reus: Multi-element characterization of tobacco smoke condensate; Fresenius J. Anal. Chem. 348 (1994) 218-225.

14. Wu D. and S. M. Larson: Determination of the elemental distribution in cigarette components and smoke by instrumental neutron activation analysis; J. Radioanal. Nucl. Chem. 217 (1997) 77-82.

15. Rauhamoca, M.H., S.S. Salmela, A. Leppanen and H. Pyysalo: Cigarette as a source of some trace and heavy metals and pesticides in man; Arch. Environ. Health 41 (1986) 49-55.

16. STATGRAPHICS, Statistical Graphics System by Statistical Graphics Corporation; User's Guide-System, STSC Inc., Rockville, MD, USA, 1986.

Address for correspondence:

Environmental Pollution Control Laboratory,

Department of Chemistry,

Aristotle University,

GR-540 06 Thessaloniki, Greece 